\title{
KEGAGALAN MERAIH CINTA DALAM CERPEN TERHENTI LANGKAHKU KARYA AJENG DWI WARDANI (SEBUAH PENGKAJIAN SASTRA)
}

\author{
Adelina Ginting \\ Dosen Universitas Katolik Santo Thomas adelinaginting57@gmail.com
}

\begin{abstract}
ABSTRAK
Pengkajian ini bertujuan untuk memaparkan sebuah karya sastra yang berjudul Terhenti Langkahku oleh Ajeng Dwi Wardani. Cerpen ini dipublikasikan pada cerpenmu.com lolos moderasi pada 16 Juni 2020. Kajian sastra ini menggunakan metode kerangka teori semantik untuk memahami kegagalan meraih cinta. Tokoh dalam cerpen ada 3 orang yakni Aku (Aji), Zilla, dan Dhika. Aji seorang pria yang baik hati, penuh perhatian, ragu-ragu dalam mengambil keputusan, Zilla gadis yang tabah, sabar, baik hati, dan Dhika pemuda yang jahat (berselingkuh) tidak setia. Kegagalan meraih cinta akibat dari keragu-raguan dalam mengambil keputusan.
\end{abstract}

Kata kunci : Cerpen, Kajian Sastra, Teori Semantik

\begin{abstract}
The purpose of this study is to explained a literary work entitled Terhenti Langkahku by Ajeng Dwi Wadani. This short story was published in cerpenmu.com and passed moderation on June $16^{\text {th }}, 2020$. This literary study uses semantic theoretical framework to understand about the failure to get love. There are 3 characters in this short story those are Aji, Zilla, and Dhika. Aji is a kind man, attentive, hesitant in making decision, Zilla is brave girl, kind-hearted, and Dhika is wicked man (having an affair) and unfaithful. The failure to get love as the result of hesitation of making decisions.
\end{abstract}

\section{Keywords : Short Story, Literary Studies, Semantic}

\section{PENDAHULUAN}

Cerpen merupakan salah satu bentuk karya sastra yang berbentuk prosa. Membaca sebuah karya sastra cerita fiksi pada hakikatnya merupakan kegiatan apresiasi sastra secara langsung; artinya untuk memahami karya sastra dengan benar sehingga tumbuh pengertian, penghargaan kepekaan kritis yang baik terhadap sastra tersebut. (Aminudin 1995:35).

Berhubungan dengan dunia sastra setiap orang yang hendak mengkaji hasil karya sastra, harus menguasai metode-metode khusus yang diharapkan dapat lebih memahami dan menguasai objek kajiannya (karya sastra) secara ilmiah.

Menurut KBBI (1964:431) kajian dapat dsebiut juga dengan penelaahan, penelitian kajian merupakan proses, cara, perbuatan mengkaji penyelidikan, penelaahan kajian mengandung makna penelitan yang proses pelaksanaannya adalah mengumpulkan mengolah, menganalisis data secara ilmiah. Menurut arti harafiahnya, kata pengkajian dapat disamakan dengan penganalisan atau penelaahan, pengkajian sastra berarti 
penganalisan atau penelaahan sastra. Hal itu tergantung teori sastra apa yang digunakan dan metode penelitian sastra apa yang tepat digunakan. Dalam kaitan dengan pengkajian sastra, seorang pengkaji harus memiliki pengetahuan teori sastra yang cukup dan metode penelitain sastra yang mantap. Tanpa keduanya, tentu pengkaji sastra akan mengalami kesulitan dan mengkaji.

Pada mulanya pengkajian sastra hanya berkisasr pada unsur intrinsik dan ekstrinsik karya sastra. Seiring dengan perkembangan teori sastra dan metode penelitian sastra dunia, pengkajian sastra semakin berkembang cakupan dan fokus kajiannya. Pengkajian sastra mulai menggunakan teori struktural, filologi, poskolonial, etnopuitika, hermeneutika, posstruktural, posmodernis, ideologi, sastra sufi, studi budaya, semiotika, dan lain-lain. Dalam hal perkembangan metode penelitian sastra pengkajian sastra sudah mulai menggunakan analisis isi, analisis teks media dan budaya, analisis naratif, dan lain-lain.

Menurut Rafiek pengkajian sastra adalah mengkaji karya sastra secara mendalam dengan menggunakan teori sastra dan teknik analisis sastra yang tepat. Mengkaji sastra berarti menelaah karya sastra dengan menganalisis dan membahas data-data berupa kutipan kalimat atau paragraf yang mengandung masalah atau topik yang hendak kita jawab atau uraikan. Menurut Kenney (19966:5), mengkaji karya sastra adalah mengidentifikasi bagian-bagian terpisah yang membuatnya tampak (muncul ke permukaan), menentukan hubungan di antara bagianbagian, dan menemukan hubungan bagianbagian secara keseluruhan. Menurut Kenney (1966:7), dengan mengkaji karya sastra, anda akan mengembangkan keterampilan atau kecerdasan intelektual dan emosional. Pengembangan kecerdasan intelektual dan emosional akan sangat diperlukan dalam memahami karya sastra. Kecerdasan intelektual akan terlaltih dan teuji dengan baik kalau pengkajaian karya sastra itu dengan berlandaskan pada teori sastra yang kuat dan mutakhir. Kecerdasan emosional juga akan sangat menentukan berhasil tidaknya sebuah karya dikaji secara mendalam dengan menggunakan pemhaman yang kuat akan karakter-karakter yang ada dalam karya sastra. Hubungan timbal balik antara pengkajian sastra dengan kecerdasan intelektual dan emosional kiranya tidak dapat terelakkan.

Menurut Nurgiayantoro (2002:30) pengkajian terhadap karya fiksi berarti penelaahan, penyelidikan, atau mengkajim, menelaah, menyelidiki karya fiksi tersebut. Lebih lanjut, Nurgiayantoro (2002:30) menambahkan bahwa untuk melakukan pengkajian terhadap unsur-unsur pembentuk karya sastra, khususnya fiksi harus disertai kerja analisis. Nurgiyantoro (2002:vii) bahwa karya sastra terbangun atas unsur intrinsik dan ekstrinsik. Oleh karena itu, pengkajian sastra terfokus pada pengkajian atas kedua unsur tersebut. Minderop (2005) lebih banyak melakukan pengkajian sastra.

$$
\text { Langkah-langkah melakukan }
$$

pengkajian sastra menurut Raffiek (2013:3) adalah sebagai berikut:

1. Membaca karya sastra yang hendak dikaji secara berulang, sampai benar-benar isi karya sastra tersebut.

2. Menentukan teori sastra yang sesuai untuk pengkajian karya sastra

3. Menguasasi metode yang tepat, suatu karya sastra dapat dikaji dengan baik 
4. Mencari dan menemukan data yang dikaji

5. Menganalisis dan membahas karya sastra dengan didukung teori yang kuat (sesuai)

\section{PEMBAHASAN}

Artikel ini berisi tentang isi cerpen "Terhenti Langkahku" Ajeng Dwi Wardani sebuah cerpen remaja. Ajeng memaknai cerpen ini kegagaln meraih cinta (patah hati).

Setelah membaca artikel ini diharapkan pembaca dapat (a) menjelaskan isi cerpen Terhenti Langkahku oleh Ajeng Dwi Wardani (b) dapat memahami kegagalan meraih cinta dan (c) membedah kegagalan meraih cinta dalam cerpen Terhenti Langkahku.

\subsection{Cerpen Terhenti Langkahku}

Cerpen Terhenti Langkahku Ajeng Dwi Wardani adalah cerpen baru di publish di dunia maya lolos moderasi pada: 16 juni 2020 kategori: cerpen cinta patah hati, cerpen ini di publish pada cerpenmu "8 Tahun Cerpenmu"

Cerpen ini merupakan, angkatan 2000an atau sastra cyber yang sangat berkembang oleh penulis-penulis muda, dan jika diberi kesempatan seperti ini penulis muda ini akan semakin baik hasil karyanya ke depan. Perlombaan peunlisan cerpen yang dikelola melalui dunia maya ini dapat mengembangkan kreativitas kaum milenial, sebagai pengembangan bakat cerpen Terhenti Langkahku ditulis oleh seoran mahasiswa sebuah PTS di smester 3 prodi komunikasi.

Cerpen Terhenti Langkahku menyoroti tentang seorang pria yang gagal meraih cintanya. Ajeng mencoba memaparkan bagaimana sedihnya hati seoarang wanita ketika mengetahui kekasihnya mendua hati.

"Kau tak berhenti menangis berbicara tentangnya, dia yang telah menyakiti perasaanmu, aku menahan untuk menangis, meyakinkanmu bahwa kau akan bahagia tanpanya."

"Dia udah duain aku, kenapa dia sejahat itu?"

Di sisi lain Ajeng menunjukkan kisah seorang lelaki yang jatuh cinta kepada wanita mantan kekasih sahabatnya. Namun dia menghadapi dilema dan bimbang untk memilih cinta atau sahabat.

"Terkadang memang akan pahit menerima cibiran dari seseorang yang begitu dekat dengan kita, tak terhitung berapa hari telah kuhabiskan waktu bersamanya kini semua menyadari sia-sia karena wanita.... sekarang aku harus memilih dengan baik sahabat atau cinta?... Cuma hati yang dapat berbicara dan mulut hanya terdiam impian bersama Zilla terpakasa harus kupatahkan dengan pertemuan pahit ini. Terhenti begitu saja tanpa ada salam perpisahan manis yang digenggam."

Ajeng Dwi Wardani seorang mahasiswa di Universitas Dian Nusantoro Semester 3 jurusan ilmu komunikasi "Saya baru berani menulis untuk mempublish karya saya semoga tidak mengecewakan."

\subsection{Memaknai Kegagalan Meraih Cinta}

Kerangka teori yang dapat dijadikan acuan adalah teori semantik sebelum memahami cerpen yang menjadi objek kajian, perlu dipakai terlebih dahulu pengertian cerpen (cerita pendek) menurut pendapat para ahli sebagai berikut Jabrohim (2001) menyatakan bahwa cerita pendek merujpakian cerita fiksi bentuk prosa yang singkat, padat yang unsur-unsur ceritanya terpusat pada satu peristiwa pokok sehingga jumlah pengembangan prilaku terbatas dan 
keseluruhan cerita memberikan kesan tunggal. Menurut Thuhar (2009:5) cerpen adalah sesuai dengan namanya cerpen tentulah pendek. Jika dibaca, jalannya di dalam cerpen lebih padat sedangkan latar maupun kilas baliknya disinggung sambil lalu saja. Di dalam cerpen hanya ditemukan sebuah peristiwa yang didukung oleh peristiwa-peristiwa kecil lainnya. Dari pendapat para ahli di atas dapat dipahami bahwa cerpen adalah sebuah karya sastyra yang bentuknya prosa isinya singkat, padat dan berfokus pada satu peristiwa saja.

Kegagalan meraih cinta adalah gagalnya atau terhentinya usaha untuk mendapatkan cinta dari lawan jenis. Konsep yang benar dalam mendapatkan cinta seorang kekasih berujung dengan ketidaksusesan (kegagalan cinta). Kegagalan meraih cinta adalah hal yang biasa dalam proses mencari cinta (kekasih). Kegagaln meraih cinta itu dapat dijadikan suatu pelajaran yang berharga untuk dapat memperbaiki dan menghindari penyebab-penyebabnya. Kegagalan meraih cinta adalah kesuksesan yang tertunda. Oleh karena itu bagi orang yang gagal dalam mendapatkan cinta seseorang, jangan bersedih hati (Raffiek 2013:106).

Dhika adalah seorang laki-laki yang jahat, mendukaan kekasih, tidak setia pada kekasih dan tidak setia kawan.

Cerpen Terhenti Langkahku dimulai dengan pertemuan Aji dan Zilla (1) yang selalu menceritakan tentang mantan kekasihnya (sahabat Aji) (2) Aji memahami arti tangisan Zilla, dan mencoba selalu menemani di saat sedih (3) hubungan Aji dan Zilla berlanjut melalui medsos (4) saling menaruh hati (5) Berani mengambil resiko berdua (6) Aji bimbang dan tak berdiri melanjutkan hubungan dengan Zilla karena rasa kuatir yang mengganggu pikirannya bahwa ia jatuh hati kepada mantan sahabatnya.

Kegagalan meraih cinta dalam cerpen ada 2 peristiwa yang berbeda. Pertama gadis (Zilla) diselingkuhi oleh mantan kekasihnya. Ia sangat bersedih dan selalu menceritakan kekasihnya kepada pria (Aji) adalah sahabat kekasih zilla.

\subsection{Membedah Kegagalan Meraih Cinta dalam Cerpen Terhenti Langkahku}

Pembahasan berawal dari deskripsi tokoh utama yaitu: Zilla, Aku (Ajie), Dhika. Cerpen Terhenti Langkahku di publish pada Cerpenmu (8 Tahun Cerpenmu) merupakan komunitas penulis cerpen Indonesia kumpulan cerpen karya anak bangsa. Terhenti Langkahku oleh Ajeng Dwi Wardani Kategori: cerpen cinta, cerpen patah hati lolos moderasi pada 16 Juni 2020 (giveaway event cerpenmu.com)

Cerpen ini tak terlalu panjang yaitu terdiri atas 32 paragraf. Tokoh utama Zilla ada seorang gadis yang patah hati karena kekasihnya Dhika mempunyai pacar yang lain. Zilla gadis yang tabah dan baik hati. Aji (Aku) adalah seorang pria yang bermurah hati, raguragu dan tidak tegas dalam mengambil keputusan. Aji selalu mau menemani Zilla yang bersedih karena patah hati diselingkuhi pacarnya (yang juga sahabat Aji). Pertemanan antara Zilla dan AJi akhirnya menimbulkan rasa menyayangi.

Di tengah perjalanan percintaan mereka ada keraguan di dalam pikiran Aji, kuatir akan akibat yang dia terima dari ejekan sahabatnya dan cibiran dari teman-temannya jika percintaan ini dilanjutkan.

Pada akhir cerita kegagalan hati Aji, dia ungkapkan kepada Zilla, bahwa dia takut 
apa kata shaabt dan teman-teman bila mereka mengetahui dia jatuh cinta pada mantan sahabatnya.

Gambaran yang dikuatirkan Aji dapat dirasakan pahit menerima cibiran dari seseorang yang begitu dekat dengan kita.

"Hari-hari bersamanya aku menjadi sia-sia karena waktu aku paham perasaan Dhika setelah tahu aku berpacaran dengan Zilla. Dhika tak berhenti menyindirku di hadapan banyak orang. Sekarang aku harus memilih dengan baik sahabat atau cinta". Keputusan yang diambil Aji yang mengakibatkan Zilla haru patah hati untuk kedua kalinya : dengan berulang air mata Zilla pergi meninggalkan Aji. Pilihan yang terakhir membuat terhenti langkahku.

Ajeng Dwi Wardani menggambarkan peristiwa atau terjadinya kegagalan meraih cinta dengan baik, tidak berbelit-belit, kalimat yang dipergunakan sederhana, mudah dipahami.

Peristiwa terjadinya kegagalan meraih cinta disebabkan keragu-raguan, rasa bersalah, ketakutan dicibir dan diejek teman sehingga cinta berakhir.

Ajeng Dwi Wardani mampu memulai cerita dengan keluhan seorang gadis (Zilla) yang patah hati karena diduakan oleh kekasihnya (Dhika), curhahan hati si gadis disampaikan kepada sahabat mantan kekasihnya. Rasa empati yang menyebabkan awal jatuh cinta yang ke-2 bagi si gadis. Awalnya mereka sangat yakin untuk menjadi cinta, tetapi sayang sang pemuda, tak berani menerima konsekuensi yang harus dia hadapi, saat-saat terakhir keputusan yang diambil mengakibatkan kegagaln meraih ceritanya. Demikian pada si gadis dia sudah berjuang melupakan cintanya dengan mantan, untuk meraih cinta baru dengan sahabat mantannya, namun tidak berhasil meraihnya.

\section{KESIMPULAN}

Cerpen Terhenti Langkahku memberi gambaran bahwa dalam menjalani hidup kita dapat jatuh cinta, namun seiringnya waktu kegagalan dapat terjadi karena perselingkuhan. Kegagalan membuat kita menjadi sedih dan menangis, biasanya akan mencari tempat curahana hati agar beroleh kelegaan. Tempat curahan hati karena dan rasa empati, hal ini dapat membuat jatuh cinta. Akibat terlalu cepat percaya kepada seseorang dapat berujung kegagalan yang kedua. Wanita jangan terlalu mudah jatuh hati. Pikir itu pelita hati. Pria jangan sakiti hati wanita.

\section{DAFTAR PUSTAKA}

Aminudin. 1995. Pengantar Apresiasi Karya Sastra. Bandung: Sinar Baru

Jabrohim. 2001. Metodologi Penelitian Sastra. Jakarta: Pustaka Jaya

Limbong, T., \& Simarmata, J. (2020). Menentukan Matakuliah yang Efektif Belajar Daring (Belajar dan Ujian) dengan Metode Multi-Attribute Utility Theory (MAUT). Jurnal Resti, 4(2), 370-376.

Rafiek, M. 2010. Teori Sastra Kajian Teori dan Praktik. Bandung: PT Refika Aditama . 2013. Pengkajian Sastra: Kajian Praktis. Bandung: PT Refika Aditama

Rohman, Saifur. 2012. Pengantar Metodologi Pengajaran Sastra. Yogyakarta: AR-RUZZ MEDIA 